\title{
An Icon for a New Woman: A Previously Unidentified Portrait of Isabella Andreini by Paolo Veronese
}

A recent conference in Naples allowed me to visit a superb exhibition at the Museo Nazionale di Capodimonte where, in the great gallery of the Palace, a series of masterpieces demonstrated the art of Italian Renaissance portraiture. ${ }^{1}$ Almost at the end of this fascinating sequence, I came across a portrait whose originality of concept and intriguingly presented female sitter inspired me with a keen interest to understand how such a portrait came to be composed. By Paolo Veronese, and owned by the Thyssen-Bornemisza Museum in Madrid, the portrait is now considered one of the last, if not the last, of this great painter's rare female portraits (Plate 5). ${ }^{2}$ It portrays a beautiful young woman in three-quarter length, slightly turned to her right, and leaning in a graceful but vigorous attitude against the dark background drape. In perfect contrast, she remains fully lit, and the light seems to play on her, breathing on the blue and white silk of her skilfully painted gown and undergown, and caressing the bright skin of her beautiful and noble face, only a small part of which, on the side to which she is slightly turned, fades into the half-light. As Hendy notes, 'no exaggerated curve or trace of mannerism in the drawing spoils the vital rhythm and balance of the pose, and there is not a superfluous touch of paint to detract from the spontaneity of the effect'. ${ }^{3}$ The woman's absorbed expression is characterized by her pensive gaze, which eludes the viewer's eyes, and by her smooth, wide forehead, left completely uncovered and discreetly framed by golden curly hair, following the shape of her head so closely that it gives the impression of a short haircut. ${ }^{4}$ The relative simplicity of her dress accords with an apparent lack of jewellery, or other signs of social identification, or indeed any specific feminine adornment that might identify her as a married woman, unmarried girl, or daughter of a particular social group.

This approach is consistent with Veronese's late style, particularly as shown in paintings characterized by figures with intense expressions, emerging from dark backgrounds with seemingly intentionally faded glazes. In fact, the most respected Veronese scholars have recently suggested dating this portrait - whose autograph status is now firmly established - to the last years of Veronese's activity, from 1585 to 1587 or $1588 .{ }^{5}$ Superficially, the sitter's enigmatically unadorned appearance could be interpreted as an affectation, deliberately intended to obscure her social rank. In fact two features indicate the possibility that this young woman belongs to an exceptional social class. 
First, an elegant toy spaniel sits on the table beside her, with a delightful sparkle in his eyes, and looking in the same direction as his mistress. At the end of the sixteenth century this breed — the drop-eared phalène - achieved the status of a fashionable accessory, becoming so popular at European courts that it is frequently depicted in portraits of royalty and nobility, particularly of ladies. In the same exhibition at Naples, for instance, a portrait by Scipione Pulzone ${ }^{6}$ showed an elegant and ornately adorned lady with her pet phalène. Drop-eared toy spaniels accompany both female and male sitters in Veronese's portraits, ${ }^{7}$ and also make their vivid appearance in his fresco cycles and religious paintings, ${ }^{8}$ where they are at the Virgin's feet in two Annunciations. ${ }^{9}$ The second feature possibly indicating the status and intellectual aspirations of the sitter is the small book (in $12^{\circ}$ or in $8^{\circ}$ ) held in her left hand, kept half-open with her thumb and close to her body, as if her reading of it had been recently interrupted. Not a word is legible on the printed page, but the book's size might, for example, suggest a 'Petrarchino', whose ownership at that time was intended to denote noble feelings and a refined intellect. ${ }^{10}$ Contemporary portraits of gentlewomen holding a 'Petrarchino' became a fashion, and may be considered visual landmarks of women's intellectual selffashioning during the course of the sixteenth century, even though young men were not uncommonly portrayed with a 'Petrarchino' either. ${ }^{11}$ Usually, the printed book is left open, exposing legible words or verses identifying the poetic text. The association with Petrarch's verses, sometimes accompanied by a demonstrative gesture, encourages the viewer to seek the metaphorical meaning encoding the sitter's intimate feelings. One example close to the period and context is the portrait of Woman holding a Petrarca, once attributed to Veronese. ${ }^{12}$ It depicts an ornately adorned and sophisticated young lady ostentatiously holding a very small book, probably a printed edition in $24^{\circ}$ in an expensive Venetian binding clearly impressed in gold with the name 'Petrarca'. In contrast to such examples, the text printed in the half-opened book in our portrait is conspicuously illegible to the viewer. This absence of indications identifying the book complicates inquiries into the artist's intention in depicting it, beyond the simple assertion that reading is a not insignificant occupation in this young woman's everyday life. As in other important portraits by Veronese, a note of intimacy here implicitly breaks through the conventions of formal portraiture.

Another aspect of the Thyssen-Bornemisza portrait that deserves attention is the dress, attractive in its own right and painted with extreme care. In 1964, Hendy remarked that every aspect of it 'is so clearly described that a modiste 
could no doubt reconstruct it in detail', and particularly noted the complete harmony between the depicted woman and her dress: it is all in one with her person, which is no less clearly defined'. ${ }^{13}$ In 1982 the Musée du Louvre acquired a group of ten drawings by Veronese, including the study for this portrait (Figure 1); Roseline Bacou, in her analysis of the group, recognized it as 'almost certainly from the hand of Veronese himself'. ${ }^{14}$ This important discovery, which subsequently supported the attribution of the painting to Veronese, is also relevant to an understanding of the relationship between the sitter and the dress in the finished portrait. The drawing confirms that we are dealing here with an exceptional style of dress, and an exceptional way of wearing it.

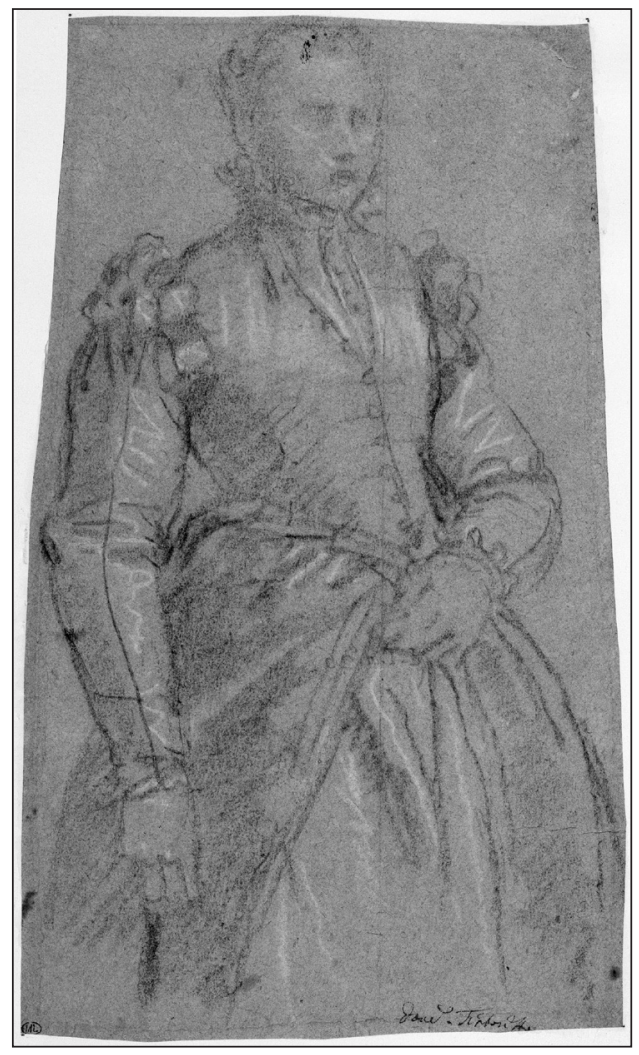

Fig. 1. Veronese (Paolo Caliari, 1528-1588), Study for the Portrait of a Woman, drawing, 299 x 175 mm. Musée du Louvre, Arts graphiques, n. inv. RF38929. () Réunion des Musées Nationaux. 
William A. Rearick considers the drawing to be intimate and ethereal, a contrast to the polished portrait in which the idealized and formalized features of the sitter appear to correspond to the painter's adulating gaze. ${ }^{15}$ I don't agree. Compared with the painted portrait, in which the woman's posture suggests energy, the drawing shows a passive figure: the body seems to be merely supporting the dress, which evidently was of interest in itself, requiring the careful attention of the portraitist. The drawing precisely depicts the distinctive style of dress worn by the young woman: the open gown's ensemble (sopravveste) consists of an overskirt parted at the waist in an inverted V-shape and a generously fitted sleeveless bodice. It is buttoned at the front and has a $\mathrm{V}$-shaped opening crowned by a small standing collar; its slightly pointed waistline with a narrow tabbed basque has been softly adjusted to the natural waistline. On the shoulders, the double wings are slashed, with puffs of the chemise sleeves pulled through. A simple ruff of moderate proportion, drawn in closely around the neck, enriches the highnecked under-gown (sottana). This collar is complemented by matching wrist ruffs at the ends of the sleeves.

This selective choice of elements also typifies the painted dress, highlighted by an elegant colour scheme, as refined as it is harmonious. The blue open gown is edged with gold braid. The bodice is centrally fastened by small gold buttons. The matching raised shoulder bands, through which rounded puffs of the chemise sleeves are pulled, achieve a striking chromatic effect. The smooth and glittering silk fabric of the undergown, with its pattern of contrasting stripes, enhances the interplay between blue and white. ${ }^{16}$ The slenderness of the figure, heightened by the unified colour of the open gown, is here accentuated according to the custom of contemporary fashion. The cloth used for the upper part of the undergown has been cut on the bias, and the convergent lines of the stripes add height to the trunk. Using two pieces for the sleeves in order to produce the aesthetic herring-bone effect along the external seam also achieves a more comfortable fit. The skirt has been cut to give horizontal stripes. The oblique and horizontal stripes accentuate a pose that might be considered slightly awkward in a female portrait, but here is seemingly designed to display the pattern of the skirt. The sitter leans against the table, with her right leg brought forward to widen the opening of the overskirt, whose rich pleats are probably supported by a padded hem, in the absence of any other sort of rigid understructure.

This neat sartorial creation happily combines sophistication and simplicity. Relative economy of means achieves maximum effect, without 
employing any brocade or other type of richly patterned or more expensive fabric. This dress fits the body more comfortably than stiff contemporary feminine fashions, and looks as if it might facilitate unrestricted movement. The bodice, which has been cut like a man's doublet, echoes men's fashion. ${ }^{17}$ Significantly, this distinctive bodice also features in costumes of Venetian prostitutes. ${ }^{18}$ Cesare Vecellio's costume book notes that while their garments varied with respect to the quality of the cloth, their dresses were generally typified by a masculine cut, their bodices, in particular, recalling men's doublets, which were centrally buttoned, and not stiffened by bones. The prostitute in the woodcut illustrating Vecellio's text leaves her bodice partly unfastened to display her sensuous décolleté (Figure 2). Her smiling face and sidelong glance appeal to the male viewer's erotic imagination, as does her gesture: she parts her skirt to reveal her shapely legs under her transparent chemise and breeches. Here too, the cloth of the bodice and of the matched sleeves seems to have been cut on the bias, with the same elongating effect of convergent lines noted in the ThyssenBornemisza portrait. Many elements of the two dresses have obvious similarities, as do some aspects of the two women's attitudes, in revealing and yet not revealing the lower part of the body and/or dress. But in the woodcut the courtesan flirts with the viewer, ${ }^{19}$ while Veronese's young woman looks straight ahead, and her pensive eyes avoid the viewer's gaze. In the portrait, moreover, the general treatment of the sitter's pose is monumental, and this quality must signify some quite different and specific meaning. The alluring pose is gone, and the manly cut of the dress perfectly matches the sitter's masculine and almost heroic attitude, reinforced by the complete absence of the type of accessories - such as jewellery or adornments - which typically played a major role in women's appearances.

Previous art historians who have considered this portrait have neither discussed these signs, nor made any suggestions regarding the sitter's identity. Some earlier scholars even excluded this paint-

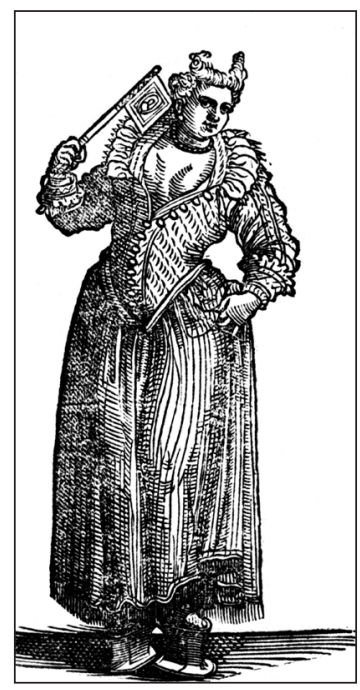

Fig. 2. Christoph Krieger (Cristoforo Guerra), Meretrici publiche (detail), woodcut from Cesare Vecellio, De gli habiti antichi et moderni di diverse parti del mondo libri due (...) (Venice, Damian Zenaro, 1590). (C) Dipartimento di Storia delle Arti, Università degli Studi di Pisa. 
ing from Veronese's oeuvre. Many of the aspects of this portrait that I discuss here have close links with the exceptional personality of its sitter, whom I here identify for the first time as the celebrated actress and poet Isabella Canali Andreini of Padua (1562-1604). Historians of the early commedia dell'arte are familiar with the artistic identity of this famous Innamorata of the Gelosi troupe, and will not be surprised to learn that she was honoured with a portrait by a great painter. Veronese, who regarded himself above all as a history painter, might ordinarily refuse commissions of this type, but Andreini was a special case.

From around 1580, Andreini's fame grew, peaking in 1588-9 when, after the publication of her pastoral play Mirtilla, ${ }^{20}$ she appeared on stage as a veritable star in the court festivities for the wedding of Ferdinando de' Medici and Christine of Lorraine, in Florence in 1589. Mirtilla combines adherence to classical sources (notably Virgil, Theocritus, and Ovid) with imitation of Petrarch and Tasso 'in a sophisticated display of erudition'. ${ }^{21}$ The publication of her poems, Rime, followed in $1601 .^{22}$ Her public image as an accomplished poet was crowned by the appreciation of contemporary eminent poets and academicians, who dedicated poetic compliments to her and corresponded with her on moral and intellectual subjects. Her husband, the equally famous Francesco Andreini (c. 1548-1624), renowned for his stage role of 'Capitan Spavento', published her Lettere, ${ }^{23}$ a collection of fictional letters on love and related moral topics, in a posthumous edition of 1607 . Recently, many scholars have investigated Isabella's complex and fascinating personality, drawing on her literary production, which reveals a great deal of her character, both in life and on the stage. ${ }^{24}$ Despite this increasing interest, our knowledge of her early career as an actress is relatively poor. Most of what we know about her post-dates 1587 , and is inevitably influenced by her public image, fashioned successively by herself, her husband, and their son.

Most contemporary visual depictions of Isabella are not useful bases of comparison for the Veronese portrait's iconography. The known iconography of Isabella - limited to portraits engraved for inclusion in her published works - strictly corresponds to her image as poet and 'Accademica Intenta', the title she assumed on being received as a member of the pretisgious Academy of the Intenti in Pavia. Such official and public iconography, commissioned for printed publication, mainly features her authorial image. Her head, with more or less accurately rendered features, is depicted with her hair in a formal style consistent with academic expectations of a book's frontispiece. The commemorative French medallion cast in her honour when she 
died in Lyons in 1604 features a heavy woman conforming to the taste of the approaching Rubens era. ${ }^{25}$ Absolutely irrelevant for the purposes of comparing Isabella's features are the small tondo portrait in Milan's Museo della Scala and a standing figure allegedly portraying her in one of Bernardo Poccetti's frescos for SS. Annunziata in Florence. ${ }^{26}$ Both these well known portraits - painted after Isabella's death — derive from extant iconography: the first from printed portraits available at the time, the second probably from the French medallion. ${ }^{27}$ No other image of Isabella has been plausibly identified in the late sixteenth-century commedia dell'arte iconography more or less tentatively connected with the Gelosi. ${ }^{28}$ With all of this, we are dealing with the conventions of popular or genre imagery, rather than accurate portraits. As the portrait of the actress poet that is probably chronologically closest to Veronese's painting, the anonymous woodcut relating to the edition of her Mirtilla of 1588 could serve as a useful comparative image, even though it renders her features without any great refinement (Figure 3). ${ }^{29}$ Here, though, for the purposes of comparison I intend to rely exclusively on the copper engraving by Raphael Sadeler the Elder (c. 1560-1628 or 1632), even though it post-dates Veronese's portrait by many years. Evidently commissioned in 1602 by Isabella to provide her Rime with a portrait by a prominent artist (Figure 4), ${ }^{30}$ this portrait - the work of an excellent engraver - may provide a faithful and reliable reproduction of the actress's features. Isabella was probably satisfied with Sadeler's work, as the plate appears in the posthumous two-volume Rime published in 1605 by her husband, who confirmed its reliability as a portrait by re-using it in his 1607 edition of the Lettere. ${ }^{31}$ Physiognomic comparison must always be regarded as a potentially deceptive way of establishing identity in works of art. Even so, there is a noticeably close resemblance between Isabella's face in Sadeler's portrait and the face of the young woman painted by Veronese. Both likenesses depict the same perfect oval proportions, characteristic shape of the eyes (large, elongated, and distant), well-drawn eyebrows, wide forehead, small full lips, well-proportioned round chin, and regular longish nose.

If Veronese did portray Isabella Andreini, she must have sat for him in Venice sometime during the period between 1581 and 1588, as the young woman in the portrait appears to be in her early twenties and Veronese died in 1588. Isabella, born in Padua in 1562, was still very young when she first met Francesco Andreini, then a professional actor playing the 'parti di Innamorato' in the Gelosi troupe. Isabella probably began her career as a professional actress after the birth of their first son Giovan Battista, baptized in Florence 


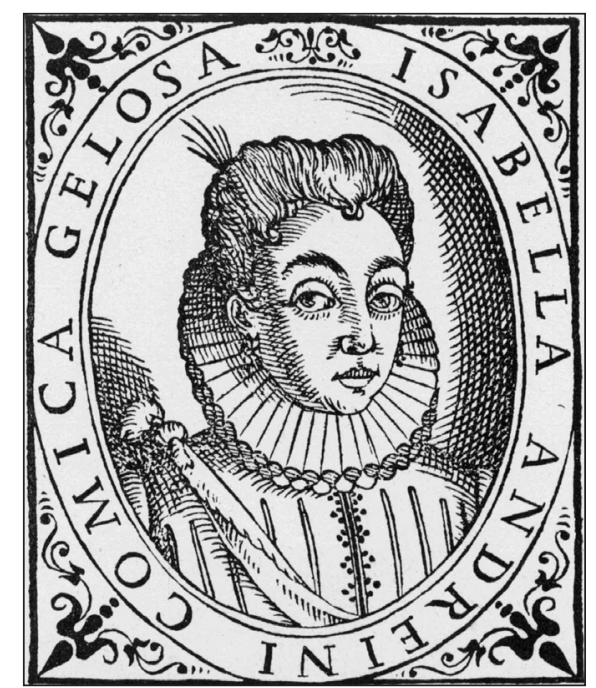

Fig. 3. Isabella Andreini Comica Gelosa, woodcut from Mirtilla Pastorale d'Isabella Andreini Comica Gelosa (Verona, Gerolamo Discepolo, 1588). (C) Dipartimento di Storia delle Arti, Università degli Studi di Pisa.

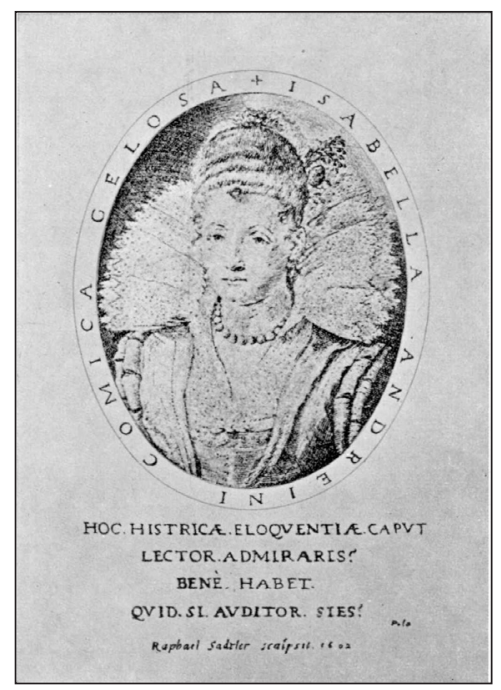

Fig. 4. Raphael Sadeler the Elder (c. 1560 - 1628 or 1632), Isabella Andreini Comica Gelosa [...], copper engraving from Lettere d'Isabella Andreini Padovana, comica gelosa, et academica intenta, nominata l'Accesa (Venezia, appresso Marc'Antonio Zaltieri: ad istantia di Gieronimo Bordon, 1607). (C Dipartimento di Storia delle Arti, Università degli Studi di Pisa. 
in February 1576. From this time to around 1580, Francesco and Isabella's whereabouts are unknown. They may have accepted an engagement on a long-term basis somewhere, independently of the Gelosi, in order to spare the repeatedly pregnant Isabella the strain of continuous touring. At that time, membership in commedia dell'arte troupes rarely remained unaltered from year to year, as individual comedians often accepted invitations to join other companies in order to obtain more advantageous contracts. So the membership of major troupes such as the Gelosi cannot be firmly established from the few documents giving more or less complete lists of the comedians in a particular troupe. ${ }^{32}$

What is certain is that, in the first month of 1583, Francesco and Isabella found themselves engaged in Venice by the nobleman Alvise Michiel, patron of the Stanza delle commedie in the Parish of San Cassan (or San Cassiano), as recorded in a letter from Francesco Andreini to Duke Vincenzo Gonzaga, written in Ferrara on April 13. ${ }^{33}$ In contrast, no documentary evidence supports the assertion that the two Andreinis - with a company independent of the Gelosi - were engaged by Michiel's stanza for the Venice Carnival of 1581. ${ }^{34}$ This season, a veritable turning point in theatre history, marked the inaugural opening in Venice of two commercial theatres, both playing to the ticket-buying public. One was this Teatro Michiel, the other, whose patron was a noble member of the Tron family, was the Teatro Tron, where another famous actress, Vittoria Piissimi, and her company, the Confidenti, were engaged for the 1581 Carnival. Significantly, around 1580, a similarly strong movement for the constitution of commercial public theatres, independent of courtly occasions, manifested itself in many theatrical capitals, including Florence, Naples, and Ferrara. ${ }^{35}$ This marked trend is a response to the first serious religious and civic attacks on professional comedians at the end of the 1570s, both in territories north of the Alps and in Italy, where professional troupes had in previous years found courtly audiences and patrons. ${ }^{36}$ The Venetian economy, free and unusually wealthy, potentially appealed to troupes trying to escape the risks of a struggle doomed to failure. Unfortunately, soon after this first extraordinary and evidently all too successful season, the Venetian Council of Ten, alerted by the Jesuits, passed an ordinance of 25 September 1581 prohibiting public theatrical performances. This decision by the public authorities distressed the noble impresario Michiel, who had invested heavily in his theatrical enterprise. The prohibition lasted until 7 December 1582. Only in 1583 did his theatre reopen for carnival, to be definitively closed shortly after the close of the seasonal entertainments. ${ }^{37}$ 
During the period between 1581 and 1583, Francesco and Isabella probably joined the Gelosi troupe and came to Venice for the carnival season of 1583, or even shortly before, to rehearse.

While in Venice, Isabella and Francesco had several opportunities for contact with Paolo Veronese. Classical theatre architecture and the perspective stage certainly influenced Veronese's great religious and allegorical compositions. In addition to this awareness of theatrical settings during his last years, Veronese might have experienced a more direct theatrical influence from the professional stage. As Veronese scholars have noted, the painter became increasingly sensitive to the pathos of expression. His figures show sophisticated and complicated body attitudes, and acquire a strong physical and spiritual presence. This new interpretative taste not only affects his historical and allegorical figures, but even inspires his portraits, to the extent that the two genres seem to merge when considered in the light of this new deep emotional response. More than simply being connected to a return to mannerist evocations, this last aesthetic phase of Veronese's art could have been influenced by the artistic qualities displayed in Venice by professional actors. Once regular theatrical activities in Venice were open to the ticket-buying public, Veronese probably frequented the stanze. He could have studied actors in performance, and could also have had regular contacts with theatre practitioners outside the theatre. His collaboration as a costume designer for the inaugural production of the Teatro Olimpico in Vicenza, ${ }^{38}$ was probably commissioned in December 1583 or early 1584, more because his artistic genius and style associated him with Palladio and Daniele Barbaro than because he was considered to have specific experience as a theatrical designer. He was probably asked for assistance by Angelo Ingegneri (1550-1613), the director of the mise-en-scène, who could have brought Veronese's drawings with him when he arrived in Vicenza in the early spring of 1584. Ingegneri was a member of the widely acclaimed theatrical avant-garde to which the Andreini couple and other outstanding comedians also belonged. Documentary evidence demonstrates close connections between the Andreinis and several of the distinguished intellectuals involved in the preparations for the inaugural performance at the Teatro Olimpico, including Ingegneri, Gregorio de' Monti, and Luigi Groto, who played the role of Oedipus in the tragedy. Possibly the Andreinis were privately engaged to play there, before the Academicians, influenced by the frequent prohibitions afflicting public theatrical performances, decided to exclude professional comedians. ${ }^{39}$ My hypothesis is that Veronese was well informed concerning the Olimpico, and that he 
participated, at least to some extent, in the initial project of the inaugural mise-en-scène, which employed professional actors. Isabella's portrait could have been painted in anticipation of this important engagement, probably in late 1583.

During these years, when for various reasons troupe membership was particularly flexible, individual comedians could acquire a strong personal artistic identity. What has correctly been interpreted as Isabella's self-shaping ability is rooted in the appreciation, shared in elevated intellectual and artistic circles, that some acting companies prided themselves on highly skilled theatrical artists whereas other troupes had less well-trained theatrical practitioners. In his comprehensive repertoire of the professions, first published in 1585, Tommaso Garzoni outlined a clear divide. On the one side, he ranged educated and honest actors and writers of comedies or tragedies, and on the other, crude performers and charlatans. ${ }^{40}$ Those comedians promoted to fame and the Andreinis were among them - could compete with other artists to earn an elevated cultural, social, and professional status, and the right to be remembered. Isabella intended to be recognized as a great actress, as a poetess, and as a perfect wife and mother. The right to be described and the right to an image became for these artists an essential demonstration of their claim to immortality, acquired thanks to literary or painted works. As Pommier noted, Giorgio Vasari first established this right in the second edition of his Vite (1568), when the Florentine painter and art historian decided to accompany the biography of each artist in his collection with a printed portrait. ${ }^{41}$ In this respect, our suggested portrait of Isabella Andreini can be meaningfully associated with two further portraits of artists by Veronese, dated by Pignatti and Pedrocco to the early 1580s: The Portrait of a Sculptor (perhaps Gerolamo Campagna) and The Portrait of an Architect. ${ }^{42}$

But why do we think that Veronese's portrait depicts a professional working woman, and, moreover, an actress? The answer is far from simple. In each of the few individual portraits of male commedia dell'arte actors that we know — dating to the years around 1600 — the mask held in the sitter's hand is an instrument of their calling and the defining symbol of their profession, and also conveys an explicit and dignified classical reference to the iconography of Greek and Roman actors. ${ }^{43}$ The masks in such portrait did not have to resemble what the actors wore in performance, because the mask itself carried a highly significant artistic reference. ${ }^{44}$ The case of the prima donna or Innamorata, the only actress in a professional company considered worthy of formal portrayal, is in principle very different. What visual symbol 
of her art could possibly manifest her profession to those who would look at her portrait? My analysis of Veronese's portrait has already highlighted the exceptional image of the sitter. Her energetic, perhaps artificial pose, results from her stage costume, and must have been perceived as an irregular and unfeminine attitude. The sitter's pose, with its marked contrapposto between the left arm and the right leg, evokes a certain type of imaginary statue standing in single architectural niches and representing allegorical and mythological female figures, such as, for example, the Muses-players in the imitation niches decorating the Sala a crociera at Maser, or Minerva and Diana in two intriguing little canvases. ${ }^{45}$ Minerva and Diana are both androgynous goddesses, whose feminine athletic body type is often denoted by a masculine energy in paintings. The Minerva's head, like the woman's head in the Thyssen-Bornemisza portrait, avoids conformity with her contrapposto body pose by looking straight ahead.

In principle, scholars have considered the energy of commedia dell'arte actors to be a specific quality of male performers, in contrast with the supposed delicacy and highly refined manners of the Innamorata. 46 Taviani's investigation of Isabella's artistic identity emphasized the poetic topos of the bella guerriera referred to in Ariosto's and Tasso's poems, which informed the androgynous image of the Innamorata. ${ }^{47}$ Recent important studies have pursued this line of inquiry, emphasizing with deeper and more focused analysis the Innamorata's energetic image and playing style and Isabella Andreini's fundamental contribution to the definition of this modern tradition. ${ }^{48}$ Anne MacNeil offers a masterly consideration of Isabella's conscious use of transgendering in her authorial practice and in what we suppose, from the rare evidence, to have been her practice as a player in both male and female roles. Andreini's theatrical self-fashioning intentionally and explicitly followed this gender dynamics, alternating between a dominant and a submissive tone. MacNeil convincingly demonstrates that this style resulted from Isabella's own creative input, and not from the opportunistic and occasional display of an androgynous sensibility. ${ }^{49}$

As the only visual depiction of Isabella Andreini which reveals such feminine/masculine playing with gender, our portrait may quite literally be regarded as a genuine demonstration of her self-fashioning. In this context, the bodice/ doublet assumed by the actress, whose form recalls the costume of public courtesans, is central. It fits the body comfortably, it can be easily opened and shown dishevelled in the mad scenes to which Isabella gave her best skills as a performer, and last but not least it was ambiguously designed to suggest both 
an erotic garment and a transgendered identity. Veronese seems to have been aware of the potential for grasping the masculine elements in this feminine frame, using the sitter's ambiguous pose and dress to signify her persona. The two accessories presented in the portrait may be considered secondary denotations. The toy spaniel, seen as the attribute of a fashionable and aristocratic lady, was probably adopted on stage by the actress who played the role of the sophisticated Innamorata. The Bavarian frescoes of the Fools' Staircase (Narrentreppe, Trausnitz Castle), feature an elegant lady, demonstrably an Innamorata, with a basket of flowers over her arm, accompanied by a lively toy spaniel (Figure 5). ${ }^{50}$ The early scenari imply that dogs and cats appeared in commedia dell'arte performances. ${ }^{51}$ As for the book, which is not specifically recognizable, it need not necessarily be a book of poetry. Probably it was simply assigned to the sitter to denote the practice of reading and studying as an appropriate activity for a cultivated woman and actress. As Giovan Battista Andreini wrote in one of his apologies for the theatrical profession, actresses rehearsed their skills through the continual reading of many different types of texts. 52

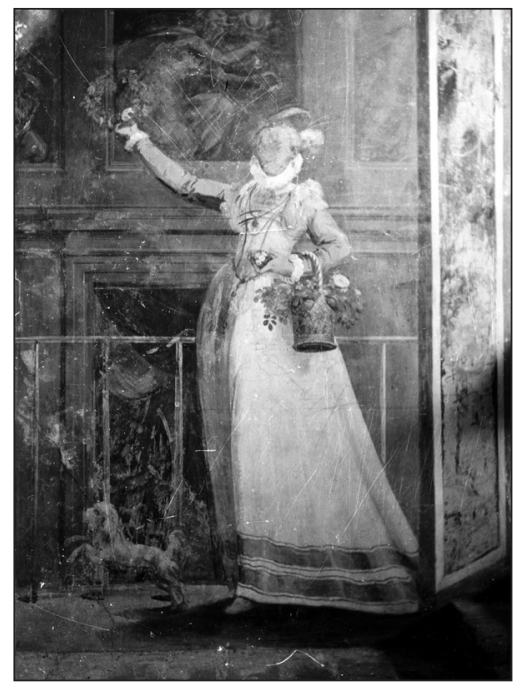

Fig. 5. Alessandro Paduano and Friedrich Sustris, Lady with Lapdog (the 'Innamorata') - Commedia dell'Arte Scenes, 1575-1579, fresco. Narrentreppe, Burg Trausnitz (Landshut, Bavaria, Germany), n. inv. SN021579. Photo: Tutschek, 1944 (pre-restoration). (C) Bayerische Verwaltung der staatlichen Schlösser, Gärten und Seen. 
The noted relationship between the preparatory drawing and the painted portrait could also be interpreted in the light of this new hypothesis. My researches have made me aware that sometimes a portrait of a comedian is not only shaped by the creative artist, but also by the creative performer. A renewed and deeper understanding of the art of portraiture is facilitated when great performers and great painters meet face to face. To explain the relationship between Veronese's portrait and its preparatory drawing, various options concerning the sitter's presentation and/or self-presentation are possible, not all of which are mutually exclusive. The first is that Veronese intended to portray Isabella in the pose outlined in the drawing, but that during the sitting she herself assumed a pose emphasizing her theatrical self-presentation. Something broadly comparable happened when Reynolds portrayed Sarah Siddons as the Tragic Muse (1784). ${ }^{53}$ The second is that the drawing is only a sketch to fix the details of the dress, ${ }^{54}$ perhaps because Veronese was well acquainted with his sitter's appearance and posture, and receptive to the experiment of finding a fictional and/or performed pose for the actual portrait. A third possible option is that Veronese was well acquainted with both the actress and the dress, perhaps because he himself had contributed to the design of the dress, or gave Isabella suggestions for its colours, design, and cut. In fact, the dress shows something of what Rearick calls 'Paolo's prolific imagination and concise understanding of costume form', 55 and could have been designed by the artist in collaboration with his actress-sitter. Significantly, a similar striped pattern is adopted by Veronese for the doublet of the servant pouring wine on the right side of The Wedding at Cana. ${ }^{56}$

A letter written by Francesco Andreini during the preparation of the Florentine festivities of 1589 notes that Isabella refused to wear cheap theatrical fabrics, or fake silver or gold decorations. ${ }^{57}$ She probably had a harmonious and sophisticated sense of what was proper and elegant on the stage and in private life, a balance between nature and artifice whose aim was to refine the normative notions of beauty established by the Petrarchan tradition. ${ }^{58}$ One of her sonnets ('Un bel semiante'), addressed to Angelo Ingegneri, who had urged her to clothe her poems in 'simple garb' and to use her 'fine, gentle words' with less artifice, opens with a poetic declaration of her canon of noble elegance:

A lovely figure in disheveled dress

Will lose its grace; and viewers will be pleased 
With well-kept gardens more than with green meads.

One hates the sun who scorns sublime delight. ${ }^{59}$

The apparent lack of adornment or precious decoration characterizing the silk dress in the portrait might correspond both to a declared taste and to an imposed norm. In Venice as elsewhere, clothing was strictly regulated by sumptuary laws. They sought to prevent actresses from being confused with noblewomen or gentlewomen by prohibiting the use of precious metals for theatrical costumes, and prohibited public prostitutes from wearing gold, silver, silk dresses, and jewels. Nevertheless, my examination of this portrait argues that Isabella made a virtue out of necessity by finding a personal style perfectly suiting her athletic charms and masculine intellectual rigour. Midway between a fashionable dress and a theatrical costume, Isabella's attire in the portrait perfectly suggests the beautiful mind ruling both her true and her assumed nature. The identification of this portrait raises many questions that cannot be addressed here, notably regarding the well-known hypothesis on the historical proximity of actresses to courtesans. My forthcoming research indicates that this proximity was more a question of social and fictional signals than any objective, widespread biographical reality. ${ }^{60}$

In the past, this extraordinary portrait was not attributed to Veronese; recent art historians seem to agree on its authenticity, but do not consider it to have been finished by the artist himself. ${ }^{61}$ In my judgement, this portrait is an exquisite and astonishingly modern composition by Veronese himself, delineating the great actress and poet of the commedia dell'arte. Crucial support for this opinion comes not simply from my recognition of Isabella's features, but from the only identification that provides a positive and coherent explanation for the portrait's exceptional formal aspects and iconography. I suggest 1583 as the most probable date for this canvas, given the likelihood that its commissioning coincided with an outstanding theatrical occasion, arguably Isabella's first appearance on the public Venetian stage, or a performance at the Teatro Olimpico. Although Michiel or some other noble patron could have played a role in this commission, I believe that the Andreinis were quite capable of attracting artistic attention in their own right. I also suggest that the provenance of the portrait (or its possible copy) and the circumstances of its passage into some French collection should be more carefully reconsidered, because the portrait was probably not commissioned for or by the sitter. 
If we compare the young woman in Veronese's portrait with the Innamorata in a well-known late sixteenth-century anonymous oil painting believed to depict the Gelosi troupe in performance, ${ }^{62}$ we cannot but appreciate the extraordinary art of the Venetian painter. The mannered expression of the Innamorata in the anonymous depiction, putting her hand to her heart, matches both her fragile, gracious attitude and her dress, which itself looks like that of a normal fashionable lady. The features of Isabella's face in this instance are not so different from those of Veronese's portrait, but in the former, we can only appreciate the stereotypical demonstration of an Innamorata, whereas in the latter we can imagine that the young woman portrayed has the intellectual and artistic power to transcend her sex.

Maria Ines Aliverti

\section{Notes}

I am grateful to the Museum Thyssen-Bornemisza and the Bayerische Schlösserverwaltung for generously granting their permission to reproduce images, and to Sara Martinez-Sarandeses and Barbara Weis for their kind collaboration. Thanks also to Raphaëlle Cartier (Réunion des musées nationaux) and Federico Bianchi (Dipartimento di Storia delle Arti, Pisa) for their help. I am also grateful to Lucia Chilosi, David Chilosi, Peg Katritzky (for revising my English manuscript), Alessandra Sirugo (Museo Petrarchesco Piccolomineo, Trieste), and my colleagues Bruna Niccoli and Marco Collareta for their useful suggestions.

1 Tiziano e il ritratto di corte da Raffaello ai Carracci, Napoli, Museo di Capodimonte, 25 March-4 June 2006, exhibition catalogue (Napoli, 2006).

2 Veronese (Paolo Caliari), Portrait of a Woman with Lapdog, oil on canvas, $105 \times 79$ cm., n.inv. 423 (1930.121). The date 1560-70 suggested by Gertrude Borghero (Thyssen-Bornemisza Collection. Catalogue Raisonné of the Exhibited Works of Art (Milano, 1986), 334, no 320), is not confirmed by recent scholarship. Philip Hendy, Some Italian Renaissance-Pictures in the Thyssen-Bornemisza Collection (Zurich, 1964), 137, offers a historical reconstruction of the portrait's ownership. For a bibliography on the portrait, see Teresio Pignatti, Filippo Pedrocco, Veronese, 2 vols (Milano, 1995), 2: 515, no A 47, and the catalogue entry (no C87) by Claudia Cremonini in Tiziano e il ritratto di corte, 342-344. In the past, Remigio Marini raised doubts concerning attribution of the portrait to Veronese and catalogued it as a possible work of Benedetto Caliari's in Paolo Veronese. L'opera completa (Milano, 1968), 130, no 292. 
Attribution became less controversial after the discovery of the study for the portrait acquired by the Cabinet des Dessins of the Louvre Museum in 1982 (see Figure 1 and below, note 14), after which general agreement on the portrait's dating, to 1585-7, was achieved. Pignatti and Pedrocco, in contrast with previous scholarship, accept the portrait as an authentic painting by Veronese in their definitive catalogue of 1995 , and agree with Rearick that Paolo Caliari definitely painted the head of the portrait, while the dress was finished by Carletto Caliari. See William A. Rearick's contribution in Paolo Veronese. Disegni e dipinti, Alessandro Bettagno (ed.), catalogue of the exhibition, Venezia, 26 March-10 July 1988 (Vicenza, 1988), 86, no 48. The theory presented in the present paper necessitates a reconsideration of all these aspects.

3 Hendy, Some Italian Renaissance-Pictures, 132.

4 This interesting detail of Venetian women's hairdressing was noted by the Milanese traveller and canon Pietro Casola, who visited the city on his way to the Holy Land in 1494: 'As to the adornment of their heads, they wear their hair so much curled over their eyes that, at first sight, they appear rather men than women'. Quoted by Raichel Le Goff in 'Mistresses and Courtesans: A Discussion of the Erotic Appeal of the So-Called Belle Donne Portraits Concentrating on the Works of Palma Vecchio and Titian', presented at the Courtauld Institute London as a seminar (25 November 1994), 8, and now available on-line: <http://epublishincorp.com/articlesraichel/ArtResearch/N-corteg.htm>.

5 Pignatti and Pedrocco, Veronese, 2: 313-27.

6 Collezione Koelliker, Milano.

7 See the Portrait of a Lady with Lapdog in the Prado Museum, Madrid, and the Portrait of Francesco Franceschini in the Ringling Museum, Sarasota. A Lady with Lapdog (a drop eared spaniel) in The Metropolitan Museum, New York, was once catalogued as a Veronese portrait by Detlev von Hadeln, Paolo Veronese. Aus dem Nachlass des Verfassers herausgegeben vom Kunsthistorischen Institut in Florenz, Gunter Schweikhart (ed.) (Florenz, 1978), no. 210, illustration 123.

8 See Jan Bialostocki, 'I cani di Paolo Veronese', Nuovi studi sul Veronese, Massimo Gemin (ed.) (Venezia, 1990), 222-30. Erika Billeter briefly considers Veronese's portrait in relation to two portraits featuring toy spaniels, Bronzino's Lady with Lapdog, 1532-4 and Titian's Portrait of Eleonora Gonzaga, 1536-7, in Hunde und ibre Maler zwischen Tizians Aristokraten und Picassos Gauklern (Wabern [u.a.], 2005), 45-6.

9 Thyssen-Bornemisza Museum, Madrid; Suida Collection, New York.

10 Petrarch's Canzoniere had many early sixteenth-century abridged editions, from Rerum Vulgarium Fragmenta, edited in Venice by Pietro Bembo in 1501, onwards. Petrarchism took hold in Europe, influencing many aspects of the contemporary poetical and musical world. 
11 Andrea del Sarto's Woman with the 'Petrarchino' (Galleria degli Uffizi, Florence) and Agnolo Bronzino's portrait of the poet Laura Battiferri (Palazzo Vecchio, Florence) are by far the most celebrated.

12 Von Hadeln, Paolo Veronese, no 205, illustration 124.

13 Hendy, Italian Renaissance-Pictures, 132.

14 Study for the Portrait of a Woman, Musée du Louvre, Arts graphiques, Inv. RF 38 929, black chalk, heightened with white, on blue-gray paper, 299 x 175 mm. See Roseline Bacou, 'Ten Unpublished Drawings by Veronese Recently Acquired by the Cabinet des Dessins du Louvre', Master Drawings 21.3 (1983), 255-262, plates 1-10, particularly 259, plate 6.

15 Rearick, Paolo Veronese. Disegni e dipinti, 86.

16 Rosita Levi Pisetzky briefly discusses the dress, dating it to around 1580, in her Storia del costume in Italia, 5 vols (Milano, 1964-9), 3 (1966), 59 and plate 26. She suggests that satin was employed for the gown, and taffeta for the undergown.

17 See also the similar cut of the bodice worn by Queen Elizabeth I in the Darnley Portrait, painted c. 1575 perhaps by Federigo Zuccaro, National Portrait Gallery, London, discussed in Aileen Ribeiro and Valerie Cumming, The Visual History of Costume (London, 1989), 89-90.

18 See Cesare Vecellio, 'Meretrici de' luoghi publici', De gli habiti antichi et moderni di diverse parti del mondo libri due (Venice, 1590), unpaginated.

19 See what Raichel Le Goff says on the Belle Donne portraits: 'what constitutes the erotic appeal in these pictures is not only a number of formulaic characteristics such as the long blonde hair, the white chemise and the bright drapery, but the overall impression that these women are in a sense, "flirting" with the viewer. The sidelong glance, the dishevelled state of dress and the gestures, invite lust'; see Le Goff, 'Mistresses and Courtesans', 7.

20 Mirtilla Pastorale d'Isabella Andreini Comica Gelosa (Verona, Gerolamo Discepolo, 1588). The verse drama was reissued many times between 1588 and 1620; see Maria Luisa Doglio's introduction to the contemporary edition, Isabella Andreini, La Mirtilla, Maria Luisa Doglio (ed.) (Lucca, 1995), 23-29, and Julie D. Campbell's introduction to her translation of Isabella Andreini, La Mirtilla: A Pastoral, Medieval \& Renaissance Texts and Studies, vol 242 (Tempe, Ariz. 2002), xii-xxvii.

21 Campbell, 'Introduction' to La Mirtilla, xiv-xvii.

22 Rime d'Isabella Andreini Padovana, Comica Gelosa (Milano, 1601), and Rime d'Isabella Andreini Padovana, Comica Gelosa \& Academica Intenta detta l'Accesa. Parte primaseconda, 2 vols (Milano, 1605). On these two editions see the reliable notes by Fabrizio Fiaschini, in Sul Tesin piantàro i tuoi laureti: Poesia e vita letteraria nella Lombardia Spagnola (1535-1706) (Pavia, 2002), 312-15, no 2.52 and 315-18, no 2.53. A se- 
lection of poems from the Rime is available in a bilingual edition (Italian-English), edited and introduced by Anne MacNeil, translated and annotated by James Wyatt Cook, as Selected Poems of Isabella Andreini (Lanham MD., 2005).

23 Lettere d'Isabella Andreini Padovana, comica gelosa, et academica intenta, nominata l'Accesa (Venezia, 1607), available in the edition of Britta Brandt, Das Spiel mit Gattungen bei Isabella Canali Andreini, 2 vols, 2: Lettere (1607), Studia Litteraria 10 (Wilhelmsfeld, 2002).

24 Further bibliographical references in: Ferdinando Taviani, 'Bella d'Asia. Torquato Tasso, gli attori e l'immortalità', Paragone / Letteratura 408-410 (February-April 1984), 3-76; Anne MacNeil, Music and Women of the Commedia dell'Arte in the Late Sixteenth Century (Oxford and New York, 2003); Culture Teatrali: studi, interventi e scritture sullo spettacolo ('L'Arte dei Comici. Omaggio a Isabella Andreini nel quarto centenario della morte (1604-2004)'), 10 (Spring 2004), Gerardo Guccini (ed.), with essays by Roberto Tessari, Paolo Russo, Paolo Fabbri, Renzo Guardenti, Cesare Molinari, Stefano Mazzoni, Franco Vazzoler, and Gerardo Guccini.

25 Reproduced in MacNeil, Music and Women, 31.

26 This fresco is dated to 1607-8. Stefano Mazzoni considers this iconographical evidence and its significance in his article 'La vita di Isabella', Culture Teatrali 10 (Spring 2004), 85-105, particularly 87-92.

27 On this anonymous portrait, and a related suggested effigy of Isabella by Cesare Dandini (1596-1657) see Maria Ines Aliverti, 'I volti di Lavinia: varianti di un' immagine d'attrice nel primo Seicento', in the forthcoming proceedings of the conference Le passioni in scena. Corpi eloquenti e segni dell'anima nel teatro del XVII e XVIII secolo, Silvia Carandini (ed.), Associazione Sigismondo Malatesta, Castello di Torre in Pietra, Torrimpietra (Roma), 18-19 November 2005.

28 On this point, see M.A. Katritzky The Art of Commedia: A Study in the Commedia dell'Arte 1560-1620 with Special Reference to the Visual Records (Amsterdam — New York, 2006), 140-65, 206 and plates 51, 61, 158, 328; 'Eight portraits of Gelosi Actors in 1589', Theatre Research International 21.2 (1996), 108-20; and Plate 1 and Figures 1 and 3 of Katritzky's article in this journal.

29 A better rendering of Isabella's face is provided by an anonymous print in the Biblioteca e Raccolta teatrale del Burcardo, Rome (reproduced in MacNeil, Music and Women, 120).

30 See Isabella Andreini's letter to Erycius Puteanus, from Brescia on 18 June 1602, in MacNeil, Music and Women, 320-321, document 42k.

31 See notes 22 and 23. The close resemblance ('l'effigie al naturale somigliantissima') of this engraved portrait is confirmed, probably on the basis of an oral tradition, by 


\section{I78 Issues in ReVIEW}

Francesco Bartoli, Notizie istoriche dé comici italiani, 2 vols (Padova 1781-1782; facsimile edition Bologna, 1978), 1: 36.

32 I think that the case for the two Andreinis being members of the Gelosi troupe before 1583 is not definitively proven, and that many nineteenth-century scholarly contributions promote ideological and unhistorical accounts of troupes, with lists of comedians and/or characters often based on defective original sources. D'Ancona had already warned scholars of the danger of this (Origini del teatro italiano. Libri tre con due appendici, 2 vols (Torino, 1891), 2: Appendice II. Il teatro mantovano nel secolo $X V I, 465-466$, n.2), and an accurate revision of these misinterpretations is overdue.

33 Archivio di Stato di Mantova, Gonzaga, busta 1256, quoted in MacNeil, Music and Women, 272-273, document 9.

34 See MacNeil, Music and Women, 9-10.

35 See the chapter 'Le stanze del teatro' in Siro Ferrone, Attori mercanti corsari (Torino, 1993), 50-88; Sergio Monaldini, 'I teatri della Commedia dell'Arte. Le prime sale, il Teatro della Sala Grande, l'ex-Cappella Ducale', I teatri di Ferrara: Commedia, opera e ballo nel Sei e Settecento, Paolo Fabbri (ed.) (Lucca, 2002), particularly 4-22, 121-8.

36 Especially from 1579 onwards, Wilhelm of Bavaria adopts an anti-theatrical policy. Documents concerning the expulsion of comedians from Mantua (the Gelosi, possibly without the two Andreinis) on 5 May 1579, and from Milan (1579) are quoted in D’Ancona, Origini del Teatro Italiano, 2: 464 and 470, n 4. Significantly, in a work first published in 1585, Tommaso Garzoni refers to expulsions due to scandals ('Discorso CIII' in La piazza universale di tutte le professioni del mondo, Paolo Cherchi and Beatrice Collina (eds), 2 vols (Torino, 1996), 2: 1180-7, particularly 1183-4. In 1578 Cardinal Paleotti calls for a ban on all theatrical activities, and specifically targets the women comedians, La commedia dell'Arte e la società barocca 1: La fascinazione del teatro, Ferdinando Taviani (ed.) (Roma, 1969), 39-40. See also Rosalind Kerr's article in this journal.

37 All these documentary sources are quoted in Franco Mancini, Maria Teresa Muraro, Elena Povoledo, I Teatri del Veneto, 1: part 1, Venezia. Teatri effimeri e nobili imprenditori (Venezia, 1995), xvi-xxvii.

38 William A. Rearick, The Art of Paolo Veronese 1528-1588, catalogue of the exhibition: National Gallery of Art, Washington, 13 November 1988-20 February 1989, (Washington 1988), 167-8, no 84. Rearick supposes that the Costume Studies for Sophocles' Oedipus the Tyrant were directly sent to Maganza, to be copied in his own drawings. He dates Paolo's sketches to the first half of 1584.

39 Stefano Mazzoni, L'Olimpico di Vicenza: Un teatro e la sua 'perpetua memoria' (Firenze, 1998), 68-70 and 141-3.

40 Garzoni, 'Discorso CIII' and 'Discorso CIV' in La piazza universale. 
41 Édouard Pommier, 'Il ritratto d'artista nell'arte italiana del XVI secolo. Saggio di tipologia', Il ritratto nell'Europa del Cinquecento, Aldo Galli, Chiara Piccinini, Massimiliano Rossi (eds) (Florence, 2007), 3-28.

42 Metropolitan Museum of Art, New York and Denver Art Museum. Pignatti and Pedrocco, Veronese, 2: 432-4, no 325 and 434-6, no 326.

43 Alberto Ambrosini, Maria Ines Aliverti, 'Sopra un ritratto d'attore inedito', Commedia dell'Arte. Annuario internazionale 1 (2008), 3-27.

44 On the iconography of actresses and their masks, see M.A. Katritzky, 'Reading the actress in commedia imagery', in Women Players in England, 1500-1660: Beyond the All-Male Stage, Pamela Allen Brown and Peter Parolin (eds) (Aldershot, 2005), $109-43$.

45 Pignatti and Pedrocco, Veronese, 2: 260, no 163 (Diana cacciatrice, Hermitage Museum, St. Petersburg); 260, no 164 (Minerva, Pushkin Museum, Moscow), now dated to c. 1580.

46 Ferdinando Taviani, 'Un vivo contrasto. Seminario su attori e attrici della Commedia dell'Arte', Teatro e Storia, 1.1 (October 1986), 25-76.

47 Taviani, 'Bella d'Asia'.

48 See Culture Teatrali, 10.

49 MacNeil, Music and Women, 95-126.

50 Figure 5 predates the fresco's restoration but postdates the serious fire which damaged the face, so that it is no longer possible to judge the extent of any facial resemblance to Isabella Andreini.

51 See for instance Flaminio Scala, Teatro delle favole rappresentative (Venice, Gio. Battista Pulciani, 1611), facsimile edition: Ferruccio Marotti (ed.), 2 vols (Milano, 1976), 2: Giornata XXXVII and Giornata L, particularly 375 and 518.

52 See the fundamentally important passage on women actresses, and specially on Isabella Andreini, in Giovan Battista Andreini, La Ferza ragionamento secondo contra l'accuse date alla Commedia (Paris, 1625), reprinted in Laura Falavolti, Attore: Alle origini di un mestiere (Roma, 1988), 65-115 (81-9).

53 Maria Ines Aliverti, La naissance de l'acteur moderne: L'acteur et son portrait au XVIIIe siècle (Paris, 1998), 162-9; see also Shelley Bennett and Mark Leonard, " "A sublime and Masterly Performance": The Making of Sir Joshua Reynolds's Sarah Siddons as the Tragic Muse', A Passion for Performance: Sarah Siddons and Her Portraitists (Los Angeles, CA., 1999), 97-140.

54 This may be compared with the costume study for the portrait of a Gentleman of the Soranzo Family (Lord Harewood, Harewood House, Leeds) dated 1586-7 in Rearick, The Art of Paolo Veronese, 192-3, no 99. Here, the drawing only depicts the dressed 


\section{I80 IsSUES IN REVIEW}

body (without head), and the posture assumed by the sitter in the portrait remains substantially unaltered.

55 Rearick, The Art of Paolo Veronese, 167.

56 Musée du Louvre, Paris.

57 Letter addressed to Emilio de' Cavalieri probably by Francesco Andreini, quoted by Angelo Solerti in 'Laura Guidiccioni Lucchesini and Emilio de' Cavalieri (I primi tentativi del melodramma)', Rivista Musicale 10 (1902), 797-829, particularly 798.

58 On this established canon of feminine beauty in Renaissance thought and literature, see Mary Rogers, 'The decorum of women's beauty: Trissino, Firenzuola, Luigini and the representation of women in sixteenth-century painting', Renaissance Studies, 2.1 (March 1988), 47-87.

59 MacNeil, Selected poems of Isabella Andreini, 189, 191.

60 On this point, see Maria Ines Aliverti, Una scena di città attribuita a Sebastiano Serlio. Breve saggio di iconologia teatrale, appendix: Della educazione delle attrici, (Pisa, 2008), in press.

61 Rearick identifies the hand of Carletto Caliari in the dress (see n. 2 above). If Cremonini (Tiziano e il ritratto di corte, 342) is correct in surmising multiple copies of this portrait, as routinely occurred with portraits of famous people, then Veronese would probably have relied on studio help.

62 Musée Carnavalet, Paris. For a good colour reproduction (detail of the Innamorata) see Cesare Molinari, La Commedia dell'Arte (Milano, 1985), 93. 